SHORT REPORT

\title{
Reactive airways dysfunction syndrome caused by bromochlorodifluoromethane from fire extinguishers
}

\author{
M Matrat, M F Laurence, Y Iwatsubo, C Hubert, N Joly, K Legrand-Cattan, J P L'Huillier, \\ C Villemain, J C Pairon
}

Occup Environ Med 2004;61:712-714. doi: 10.1136/oem.2003.009837

\begin{abstract}
Although the neurological and cardiovascular effects of Freons have been extensively described, the respiratory effects have been less well documented. We report four cases of occupational asthma following accidental exposure to bromochlorodifluoromethane (Halon 1211) due to release of the contents of a fire extinguisher. All subjects developed an irritative reaction of the upper airways and lower respiratory symptoms immediately after exposure. Non-specific bronchial hyperreactivity was present for at least two months in all subjects and was still present more than two years after exposure in one case. The diagnosis of reactive airways dysfunction syndrome can be adopted in at least three of these four cases.
\end{abstract}

B romochlorodifluoromethane $\left(\mathrm{CBrClF}_{2}\right.$, Halon 1211$)$ is a colourless and almost odourless gas widely used in fire extinguishers. The use of Halons in fire extinguishers and other protective systems against fire ceased at the end of 2003. However, some rare exceptions exist to the general ban on ozone damaging agents, as the use of Halon 1211 will still be allowed after 2003 in the European Union in four circumstances: for use in aircraft extinguishers (portable fire extinguishers, fixed motor extinguishers, extinguishers for crew compartments, engine nacelles, cargo bays, and dry bays), extinguishers for safety of firefighters (initial extinction of fires), and military and police extinguishers for use on persons. ${ }^{1}$

The acute toxicity of $\mathrm{CBrClF}_{2}$ is usually considered to be related to central nervous system dysfunction ${ }^{2}$ and cardiac sensitisation to catecholamines with lowering of the threshold for arrhythmia. ${ }^{3}$

Human exposure studies suggest that fluorocarbons can cause respiratory irritation. ${ }^{45}$ Some authors have reported respiratory irritant effects or reactive airways dysfunction syndrome (RADS) following accidental exposure to bromotrifluoromethane (Halon 1301) $)^{67}$ or thermal degradation products of Freons. ${ }^{8}$ We report four cases of occupational asthma following exposure to $\mathrm{CBrClF}_{2}$.

\section{CASE REPORTS}

The four cases occurred in two distinct episodes of accidental exposure to $\mathrm{CBrClF}_{2}$ with fire extinguishers used in aeroplanes.

\section{Incident A}

Three subjects were involved in incident A, which occurred on 24 December 1998 during a flight. Accidental release of the contents of a portable fire extinguisher occurred during handling in the absence of a fire at the back part of the plane. Three crew members, two air hostesses, and a steward were exposed while transporting the defective fire extinguisher to a closed cabinet. Passengers were not concerned by the incident. The entire contents of the extinguisher were released. The estimated exposure time for the crew members was less than five minutes. Although the level of exposure could not be accurately determined, it was considered to be probably high.

\section{Patient Al}

Patient Al was a 30 year old non-smoking air hostess with no medical history of respiratory or atopic disease. On medical examination immediately after arrival of the plane (about one hour later), she presented with signs of irritation of the upper respiratory tract. Chest auscultation and neurological examination were normal. During the days following the incident, she experienced asthenia, dyspnoea on exertion, and cough at night. She stopped her sports activities because of respiratory symptoms. Spirometry performed on 5 February 1999 showed a slight decrease in $\mathrm{FEV}_{1} \quad(80 \%$ predicted) and $\mathrm{FEF}_{25-75 \%}$ (60\% predicted), which were not improved by bronchodilators. Other spirometric measurements were normal. She consulted a hospital department of occupational medicine on 15 February 1999. Similar spirometric results were observed at this time. Bronchoscopy showed an inflammatory mucosa. Skin prick tests with the usual respiratory allergens (house dust mites, cockroaches, cat, dog, grass pollens and tree pollens (Betulaceae, Fagales, ash), mould (Alternaria, Aspergillus, Cladosporium, Penicilium) and latex) were negative. Inhaled steroids (budesonide) and a bronchodilator (formoterol) were prescribed. Fifteen months later (March 2000), a methacholine challenge was performed. At that time, patient $\mathrm{Al}$ had stopped her treatment. A $24 \%$ decrease in $\mathrm{FEV}_{1}$ was observed with a cumulative dose of $640 \mu \mathrm{g}$. Twenty eight months after the incident (April 2001), she still experienced cough at night and lung function parameters were unchanged.

\section{Patient A2}

Patient A2 was a 29 year old non-smoking air hostess with no medical history of respiratory or atopic disease. Immediately after exposure, she presented with sore throat, nausea, and dizziness. Chest auscultation, neurological examination, standard parameters, and electrocardiogram on arrival of the flight were normal. During the days following the incident, she reported the presence of cough at night and dizziness. Spirometry and chest $x$ ray examination were normal on day 5. During the following month, she suffered from palpitations and muscle pain during exercise. Four months after the incident, she still suffered from cough,

\footnotetext{
Abbreviations: $\mathrm{FEF}_{25-75 \%}$, forced expiratory flow rate at $25-75 \%$ of forced vital capacity; $F E V_{1}$, forced expiratory volume in one second; FVC, forced vital capacity; RADS, reactive airways dysfunction syndrome
} 


\section{Main messages}

- Acute exposure to bromochlorodifluoromethane may lead to RADS.

- Employees should be informed about the possible toxic effects in the case of accidental release of a Freon containing fire extinguisher.

episodes of asthenia, and dizziness, and a diagnosis of psychological post-traumatic syndrome was proposed. She had a slight decrease in $\mathrm{FEV}_{1}$ (91\% predicted), while other spirometric parameters were normal. Methacholine challenge test revealed a $28 \%$ decrease in $\mathrm{FEV}_{1}$ with a dose of $160 \mu \mathrm{g}$. Diffusing capacity for CO was normal. Bronchoscopy showed inflammatory mucosa with abundant secretions. Inhaled steroid (beclomethasone) and bronchodilator (formoterol), and an anxiolytic (bromazepam) were prescribed. Ten months after the incident (October 1999) she still suffered from dizziness and cough at night. Baseline spirometric parameters were unchanged. Methacholine challenge test was negative (cumulative dose $1920 \mu \mathrm{g}$ ) at 21 months (September 2000) and the treatment with inhaled steroids was maintained. Twenty eight months after the accidental exposure (March 2001), she still complained of cough during exercise with no modification of baseline lung function values.

\section{Patient A3}

Patient A3 was a 39 year old steward with a medical history of allergic rhinitis; he was an ex-smoker with low cumulative smoking (less than 5 pack-years). He was the most severely exposed subject. Immediately after the incident, he experienced malaise, wheezing, and limb paraesthesia. Prednisone

\section{Policy implications}

- Intervention in the case of accidental release of the contents of a fire extinguisher containing bromochlorodifluoromethane should be performed with the use of an adapted individual respiratory protection device.

was prescribed for 10 days in the emergency unit, followed by complementary treatment including inhaled steroid (budesonide) and bronchodilator (terbutaline). In January 1999, baseline spirometric values were: $\mathrm{FEV}_{1}, 90 \%$ predicted; $\mathrm{FEV}_{\mathrm{l}} /$ FVC ratio, 81\%; and $\mathrm{FEF}_{25-75 \%}$, 105\% predicted. $\mathrm{FEV}_{1}$ increased with bronchodilator (+15\%). In February 1999, he presented with dyspnoea on exertion. Baseline spirometric parameters (during treatment with budesonide) were normal. Methacholine challenge test showed a $22 \%$ decrease in $\mathrm{FEV}_{1}$ with a cumulative dose of $1280 \mu \mathrm{g}$. Inhaled steroid (budesonide) and bronchodilator (bambuterol) treatment was maintained for at least six months and the patient was subsequently lost to follow up.

\section{Incident B}

Patient Bl, involved in incident B occurring on 26 February 1999, was a 31 year old non-smoking air hostess, who tried to stop a passenger from manipulating a fire extinguisher, just before take-off. The passengers were not affected by the release of the contents of the extinguisher. The entire contents of the fire extinguisher were released and patient Bl reported that she was exposed for less than five minutes, as the door of the aeroplane was rapidly opened. Patient Bl had a medical history of childhood house dust mite induced asthma, but had not experienced any asthma attacks for 10 years. She experienced cough with dyspnoea, eye irritation,

Table 1 Respiratory characteristics of the four patients according to Brooks and colleagues' criteria9

\begin{tabular}{|c|c|c|c|c|c|}
\hline & \multicolumn{5}{|c|}{ Patient (date of the incident) } \\
\hline & $\begin{array}{l}\text { Al } \\
\text { (December 1998) }\end{array}$ & & $\begin{array}{l}\text { A2 } \\
\text { (December 1998) }\end{array}$ & $\begin{array}{l}\text { A3 } \\
\text { (December 1998) }\end{array}$ & $\begin{array}{l}\text { B1 } \\
\text { (February 1999) }\end{array}$ \\
\hline $\begin{array}{l}\text { Absence of previous respiratory } \\
\text { complaints }\end{array}$ & + & & + & + & $\begin{array}{l}\text { Childhood asthma with } \\
\text { no asthma attack for past } \\
10 \text { years }\end{array}$ \\
\hline $\begin{array}{l}\text { Single exposure to high levels of } \\
\mathrm{CBrClF}_{2}\end{array}$ & + & & + & + & + \\
\hline $\begin{array}{l}\text { Onset of asthma symptoms within } 24 \\
\text { hours after exposure }\end{array}$ & + & & + & + & + \\
\hline Symptoms lasting at least 3 months & + & & + & + & + \\
\hline Bronchial obstruction & $\begin{array}{l}\text { Obstruction of small } \\
\text { airways }\end{array}$ & & - & - & - \\
\hline $\begin{array}{l}\text { Baseline spirometry parameters } \\
\text { (percentage of predictive value*) }\end{array}$ & (February 1999) & & (April 1999) & (January 1999) & (April 1999) \\
\hline FVC (I) & $3.14(86 \%)$ & & $3.21(90 \%)$ & $4.81(91 \%)$ & $3.36(95 \%)$ \\
\hline $\mathrm{FEV}_{1}(\mathrm{l})$ & $2.55(80 \%)$ & & $2.82(91 \%)$ & $3.92(90 \%)$ & $2.92(95 \%)$ \\
\hline $\mathrm{FEV}_{1} / \mathrm{FVC}(\%)$ & $81 \%$ & & $88 \%$ & $81 \%$ & $87 \%$ \\
\hline $\mathrm{FEF}_{25-75}(\mathrm{l} / \mathrm{s})$ & $2.41(60 \%)$ & & $3.89(98 \%)$ & $4.85(105 \%)$ & $2.99(77 \%)$ \\
\hline Bronchial hyperresponsiveness & + & & + & & + \\
\hline Methacholine challenget & March 2000 & April 2001 & April 1999 & February 1999 & April 1999 \\
\hline $\begin{array}{l}\text { Maximum cumulative dose of } \\
\text { methacholine }\end{array}$ & $640 \mu \mathrm{g}$ & $1280 \mu \mathrm{g}$ & $160 \mu \mathrm{g}$ & $1280 \mu \mathrm{g}$ & $640 \mu \mathrm{g}$ \\
\hline $\begin{array}{l}\text { Percentage of fall in } \mathrm{FEV}_{1} \\
\text { Presence of other pulmonary disease a } \\
\text { the time of incident }\end{array}$ & $-24 \%$ & $-23 \%$ & $\begin{array}{l}-28 \% \\
-\end{array}$ & $\begin{array}{l}-22 \% \\
-\end{array}$ & $\begin{array}{l}-38 \% \\
-\end{array}$ \\
\hline Diagnosis of RADS $\ddagger$ & Definite & & Definite & Definite & ? \\
\hline
\end{tabular}

*The spirometric relative values were calculated using the reference values established by Quanjer et al. ${ }^{10}$

The methacholine challenge was performed with an aerosol nebuliser (FDC88, Mediprom) which delivered successively increasing doses of methacholine ( $80 \mu \mathrm{g}$, $160 \mu \mathrm{g}, 320 \mu \mathrm{g}, 640 \mu \mathrm{g}, 1280 \mu \mathrm{g}, 1920 \mu \mathrm{g})$. Delivered doses were calculated from the flow rate of the aerosol and duration of delivery. At each methacholine dose, the $\mathrm{FEV}_{1}$ measurement was done, starting 90 seconds after the inhalation. The test was stopped when a fall of at least $20 \%$ of $\mathrm{FEV}$, was observed. Total duration of the methacholine challenge and $\mathrm{FEV}_{1}$ measurements generally lasted about 20 minutes.

‡RADS, reactive airways dysfunction syndrome. 
and dizziness, which lasted six hours after the incident. She only received salbutamol (self prescribed). The respiratory symptoms improved within 24 hours, but she experienced dyspnoea in a smoky environment at night two or three times a week. When she consulted the department of occupational medicine on April 1999, she reported dyspnoea on exertion. Chest auscultation and chest $x$ ray examination were normal. Baseline lung function parameters were: $\mathrm{FEV}_{1}, 95 \%$ predicted; $\mathrm{FEV}_{1} / \mathrm{FVC}$ ratio, $87 \%$; and $\mathrm{FEF}_{25-75 \%}$, $77 \%$ predicted. The methacholine challenge test was positive at the dose of $640 \mu \mathrm{g}$ with a $38 \%$ decrease in $\mathrm{FEV}_{1}$ from the baseline value. Inhaled steroid (beclomethasone) and bronchodilator (salbutamol) were prescribed. In September 1999, she no longer experienced any respiratory symptoms on effort. Baseline spirometric parameters were normal.

\section{DISCUSSION}

The four subjects were exposed under similar conditions to inhalation of bromochlorodifluoromethane. All subjects developed symptoms of respiratory irritation with dizziness, and the steward, who probably experienced the highest level of exposure, also presented neurological symptoms.

In our study, the symptoms presented by patients $\mathrm{A} 1, \mathrm{~A} 2$, and A3 correspond to the criteria of $\operatorname{RADS}^{9}$ (table 1). All subjects presented symptoms of upper airway irritation and bronchial hyperreactivity immediately after a single exposure to a high concentration of bromochlorodifluoromethane. Halon 1211 was the only Halon in the fire extinguisher. For patient $\mathrm{Bl}$, bronchial hyperreactivity must be interpreted cautiously, as she had a medical history of asthma during childhood. However, this patient had not experienced an asthma attack for 10 years. As previously reported, an exacerbation of quiescent asthma can be considered to be a consequence of inhalation injury. ${ }^{11}$ It should be noted that symptoms were persistent (lasting more than two years) in at least two subjects.

Previous publications on the effects of Freons on human health have mainly concerned the neurological and cardiovascular effects; the respiratory effects of Freons have been less extensively studied.

Brooks and colleagues ${ }^{4}$ reported that inhalation of bronchodilator containing dichlorodifluoroethane as propellant induced an increase in airway resistance and hypoxaemia in several of a group of 13 subjects with mild to severe asthma.

Recently, de la $\mathrm{Hoz}^{7}$ reported a case of RADS after a 10-15 minute exposure to bromotrifluoromethane, a fluorocarbon widely used in automatic fire extinguishing systems.

Prolonged respiratory symptoms were recently reported following exposure to thermal degradation products of Freons. ${ }^{8}$ According to the authors, these subjects could have been exposed to hydrogen fluoride, hydrogen chloride, carbonyl fluoride, or chlorine. It should be emphasised that our subjects were exposed to Halon 1211 itself and not the products of thermal degradation, as exposure resulted from accidental release at room temperature.

To our knowledge, the cases presented here are the first reported cases of RADS following exposure to bromochlorodifluoromethane, mainly used in portable fire extinguishers, which probably explains why no occupational exposure limit has been defined for this agent in France. It is difficult to establish occupational exposure limits because the concentration of the compound must be sufficiently high to extinguish fire without causing any toxic effects on human health. This emphasises the need for preventive actions such as information for employees about the possible toxic effects of bromochlorodifluoromethane in the case of accidental inhalation of high levels of this agent.

Our study also indicates that bromochlorodifluoromethane must be added to the list of substances likely to cause RADS.

\section{Authors' affiliations \\ M Matrat, M F Laurence, C Hubert, N Joly, K Legrand-Cattan, \\ J P L’Huillier, J C Pairon, Unité de Pathologie Professionnelle, Service de Pneumologie et Pathologie Professionnelle, CHI Créteil, France Y Iwatsubo, INSERM E03-37, avenue du Général Sarrail, Créteil, France \\ C Villemain, AIMTRSP, Chevilly Larue, France}

Correspondence to: Professor J C Pairon, Service de Pneumologie et de Pathologie Professionnelle, CHI Créteil, 40 avenue de Verdun, 94010 Créteil Cedex, France; jc.pairon@chicreteil.fr

Accepted 28 November 2003

\section{REFERENCES}

1 Regulation (EC) No. 2037/2000 of the European Parliament and of the Council of 29 June 2000 on substances that deplete the ozone layer. Official Journal of the European Community, 29 September 2000: L244/1-L244/24..

2 Steadman C, Dorrington LC, Kay P, et al. Abuse of a fire-extinguishing agent and sudden death in adolescents. Med J Aust 1984;141:115-17.

3 Kaufman JD, Morgan MS, Marks ML, et al. A study of the cardiac effects of bromochlorodifluoromethane (Halon 1211) exposure during exercise. Am J Ind Med 1992;21:223-33.

4 Brooks SM, Mintz S, Weiss E. Changes occurring after freon inhalation. Am Rev Respir Dis 1972;105:640-3.

5 Valic $F$, Skuric $Z$, Bantic $Z$, et al. Effects of fluorocarbon propellants on respiratory flow and ECG. BrJ Ind Med 1977;34:130-6.

6 Holness DL, House RA. Health effects of Halon 1301 exposure. J Occup Med 1992:34:722-5.

7 de la Hoz RE. Reactive airways dysfunction syndrome following exposure to a fluorocarbon. Eur Respir J 1999;13:1192-4.

8 Piirilä P, Espo T, Pfäffli $P$, et al. Prolonged respiratory symptoms caused by thermal degradation products of freons. Scand J Work Environ Health 2003;29:71-7

9 Brooks SM, Weiss MA, Bernstein IL. Reactive airways dysfunction syndrome (RADS). Persistent asthma syndrome after high level irritant exposures. Chest 1985;88:376-84.

10 Quanjer PH, Tammeling GJ, Cotes JE, et al. Lung volumes and forced ventilatory flows. Report working party standardization of lung function tests. European community for steel and coal. Official statement of the European Respiratory Society. Eur Respir J 1993;6(suppl 16):5-40.

11 Nemery B. Late consequences of accidental exposure to inhaled irritants: RADS and Bhopal disaster. Eur Respir J 1996;9:1973-6. 